\title{
Association of the 5-HTT gene-linked promoter region (5-HTTLPR) polymorphism with psychiatric disorders: review of psychopathology and pharmacotherapy
}

\author{
This article was published in the following Dove Press journal: \\ Pharmacogenomics and Personalized Medicine \\ 12 January 2012 \\ Number of times this article has been viewed
}

\author{
George A Kenna' \\ Nick Roder-Hanna ${ }^{2}$ \\ Lorenzo Leggio ${ }^{3}$ \\ William H Zywiak ${ }^{4}$ \\ James Clifford ${ }^{5}$ \\ Steven Edwards ${ }^{3}$ \\ John A Kenna ${ }^{6}$ \\ Jessica Shoaff ${ }^{\prime}$ \\ Robert M Swift' \\ 'Center for Alcohol and Addiction \\ Studies, Department of Psychiatry \\ and Human Behavior, Brown \\ University, Providence; ${ }^{2}$ College of \\ Pharmacy, University of Rhode Island, \\ Kingston; ${ }^{3}$ Center for Alcohol and \\ Addiction Studies, Department of \\ Community Health, Brown University, \\ Providence; ${ }^{4}$ Butler Hospital, \\ Providence, RI; ${ }^{5}$ Virginia Institute for \\ Psychiatric and Behavior Genetics, \\ Virginia Commonwealth University, \\ Richmond, VA; ${ }^{6}$ College of Nursing, \\ University of Rhode Island, Kingston, \\ RI, USA
}

Correspondence: George A Kenna Center for Alcohol and Addiction Studies, Box G-SI2I-5, Brown University, Providence, RI 02903, USA

$\mathrm{Tel}+$ I 40 I 932 I534

Fax + I 40I 4566762

Email george_kenna@brown.edu
Abstract: Serotonin (5-HT) regulates important biological and psychological processes including mood, and may be associated with the development of several psychiatric disorders. An association between psychopathology and genes that regulate 5-HT neurotransmission is a robust area of research. Identification of the genes responsible for the predisposition, development, and pharmacological response of various psychiatric disorders is crucial to the advancement of our understanding of their underlying neurobiology. This review highlights research investigating 5-HT transporter (5-HTTLPR) polymorphism, because studies investigating the impact of the 5-HTTLPR polymorphism have demonstrated significant associations with many psychiatric disorders. Decreased transcriptional activity of the S allele ("risk allele") may be associated with a heightened amygdala response leading to anxiety-related personality traits, major depressive disorder, suicide attempts, and bipolar disorder. By contrast, increased transcriptional activity of the $\mathrm{L}$ allele is considered protective for depression but is also associated with completed suicide, nicotine dependence, and attention deficit hyperactivity disorder. For some disorders, such as post-traumatic stress disorder and major depressive disorder, the research suggests that treatment response may vary by allele (such as an enhanced response to serotonin specific reuptake inhibitors in patients with major depressive disorder and post-traumatic stress disorder with $\mathrm{L}$ alleles), and for alcohol dependence, the association and treatment for $\mathrm{S}$ or $\mathrm{L}$ alleles may vary with alcoholic subtype. While some studies suggest that 5-HTTLPR polymorphism can moderate the response to pharmacotherapy, the association between 5-HTTLPR alleles and therapeutic outcomes is inconsistent. The discovery of triallelic 5-HTTLPR alleles $\left(\mathrm{L}_{\mathrm{A}} / \mathrm{L}_{\mathrm{G}} / \mathrm{S}\right)$ may help to explain some of the conflicting results of many past association studies, while concurrently providing more meaningful data in the future. Studies assessing 5-HTTLPR as the solitary genetic factor contributing to the etiology of psychiatric disorders continue to face the challenges of statistically small effect sizes and limited replication.

Keywords: 5-HTTLPR, SCC6A4, 5-HT, serotonin, genetics, alleles, triallele, psychiatric, polymorphisms, pharmacotherapy, psychopathology

\section{Introduction}

Serotonin (5-hydroxytryptamine, 5-HT), is a monoamine neurotransmitter that regulates numerous important physiological processes, including sleep, food intake, pain, vascular tone, platelet function, and motor activity. ${ }^{1,2}$ However, 5-HT is perhaps best known for its mood and behavior modulating effects within the central nervous system. Consequently, 5-HT has been implicated in the pathology of numerous psychiatric 
disorders and has been a primary focus in the treatment of such diseases. The growing understanding of genetics has led to an increasing association between the genes that regulate 5-HT neurotransmission and the psychiatric disorders that have been characterized by 5 -HT dysregulation. ${ }^{3}$

In humans, 5-HT is synthesized from the amino acid tryptophan via a two-step process. ${ }^{1,2}$ Because 5-HT itself is unable to cross the blood-brain barrier, tryptophan is moved into the central nervous system by a transport protein, where it is subsequently converted to 5-HT by the enzymes tryptophan hydroxylase and amino acid decarboxylase. ${ }^{2}$ After biosynthesis, 5-HT is packaged into presynaptic vesicles in the axon terminal for storage and protection from metabolism. ${ }^{1,2}$

Following depolarization, 5-HT is released where it can bind to either a postsynaptic 5-HT receptor to induce potentiation or a presynaptic autoreceptor to induce feedback inhibition of further 5-HT release. ${ }^{1}$ Seven families of 5-HT receptors have been identified, $5-\mathrm{HT}_{1}$ through $5-\mathrm{HT}_{7}$, all of which are $\mathrm{G}$ protein-coupled receptors with the exception of $5-\mathrm{HT}_{3}{ }^{1,2}$ Currently, there are 14 unique 5-HT receptor subtypes, some with known but varied function. ${ }^{2}$ While specific receptor subtypes are associated with certain functions, such as $5-\mathrm{HT}_{1 \mathrm{D}}$ and cranial blood vessel vasoconstriction, ${ }^{1}$ the complexity of the central nervous system is such that 5-HT is able to elicit a wide variety of physiological responses through particular combinations of receptor subtypes, brain areas, and involved neurons. ${ }^{2}$

Released 5-HT remains in the synaptic space until it is either reaccumulated into the presynaptic neuron or metabolized by monoamine oxidase. The serotonin transporter protein (5-HTT), a transporter located on the presynaptic neuron, is responsible for reuptake of the neurotransmitter and represents the primary mechanism for termination of serotonergic neurotransmission. ${ }^{2}$ Reaccumulated 5-HT is repackaged into synaptic vesicles and reused. ${ }^{1,2}$ Any 5-HT that escapes reuptake by 5-HTT is inactivated by monoamine oxidase, and while both processes occur simultaneously, it is reuptake by 5-HTT that is primarily responsible for terminating the action of 5-HT. ${ }^{2}$ By this mechanism, 5-HTT is able to regulate the concentration of 5-HT in the synapse, thereby controlling the magnitude and duration of postsynaptic signaling. ${ }^{1,4}$ The genes that code for 5HTT, solute carrier family 6 neurotransmitter transporter, serotonin, member 4 (SLC6A4), and polymorphic variants, have become the most investigated in psychiatry, psychology, and neuroscience..$^{5}$

A polymorphism is a genetic variation in a segment of DNA that occurs in a population at a frequency greater than $1 \%$, resulting in the existence of multiple alleles or versions of a given gene which may be present at a locus on a specific chromosome. ${ }^{5}$ Alleles determine distinct traits, such as eye color. For example, a polymorphism may result in the existence of alleles A and B, or more, of which either may be present at a gene locus of the two chromosomes. Each allele is associated with differing functionality; hence, polymorphisms can alter the expression or activity of the gene in which they occur. ${ }^{5}$ Polymorphisms in SLC6A4 can significantly affect regulation of serotonergic neurotransmission. Expression of a gene is controlled by the promoter, a regulatory region located upstream of the protein coding region that allows RNA polymerase to bind and initiate transcription. Polymorphisms in the promoter region of the gene encoding 5-HTT have been associated with varying degrees of transcriptional activity, which leads to varying degrees of RNA synthesis and protein formation. ${ }^{4}$ SLC6A4 is located on chromosome 17 (17q11.1-q12) and contains a functional insertion-deletion polymorphism of two 22-base pair repeat elements in the promoter region, known as the 5-HTT gene-linked promoter region (5-HTTLPR). This functional polymorphism results in two possible primary allelic variations of differing length and activity, ie, a long (L) allele consisting of 16 repeats and a short (S) allele consisting of 14 repeats. ${ }^{4,6-8}$ Because humans have two copies of each chromosome, genotype combinations can include S-homozygous (S/S), S/L heterozygous, or L-homozygous (L/L). Cells homozygous for the L allele (L/L) have been shown to produce levels of 5-HTT mRNA 1.4 to 1.7 times greater than that seen in cells containing the S allele. ${ }^{4}$ Moreover, the $\mathrm{L} / \mathrm{L}$ variant was capable of removing 5-HT from the synaptic cleft at a rate 1.9-2.2 times greater than the $\mathrm{S} / \mathrm{S}$ and $\mathrm{S} / \mathrm{L}$ variants. Hence, the L-homozygous variant is associated with increased transcriptional activity of the 5-HTT promoter, resulting in increased 5-HTT expression and 5-HT reuptake from the synapse relative to that of S-containing variants.

In addition to the L/S alleles, many other genetic variations have been identified for the 5-HTT (SLC6 A4) gene. Several single nucleotide polymorphisms that can change the activity of 5-HTT have been identified. One single nucleotide polymorphism that is particularly relevant is an adenine to guanine single nucleotide polymorphism that occurs only in the long allele, resulting in its division into two distinct alleles, ie, $\mathrm{L}_{\mathrm{A}}$ and $\mathrm{L}_{\mathrm{G}}$. Evidence suggests that the $\mathrm{L}_{\mathrm{G}}$ allele may have transcriptional activity similar to that of the $\mathrm{S}$ allele, while only the $\mathrm{L}_{\mathrm{A}}$ allele increases transcriptional activity., ${ }^{9,10}$ This single nucleotide polymorphism has not been considered in many studies, and hence assessment of 
the significance and association of the $\mathrm{L}_{\mathrm{A}}$ and $\mathrm{L}_{\mathrm{G}}$ alleles is limited at this time. However, it is probable that the existence of the triallelic alleles, not known until recently, has resulted in an underestimation of the statistical and clinical effect of 5-HTTLPR. ${ }^{11}$

Studies of the association between the 5-HTTLPR variant and psychiatric disorders have often produced inconsistent results. ${ }^{11,12}$ However, for many disorders, evidence for a variant effect does exist, often with significant implications for treatment. The aim of this review is to present the current understanding of the 5-HTTLPR within the framework of psychopathology and when available, potential pharmacotherapy implications.

\section{5-HTT variants: psychopathology and pharmacotherapy implications}

The heritability of many psychiatric disorders is well known and widely accepted. However, pursuit of the specific genes responsible for the transmission of these diseases has been limited due to the relative novelty, cost, and complexity of human behavior. Since its discovery in the mid 1990s, ${ }^{13,14}$ 5-HTTLPR has received increasing attention as a risk factor for various psychiatric disorders ${ }^{4}$ and represents an attractive and heavily researched target for psychiatric genetic research (see Table 1). While both 5-HTTLPR alleles are regarded as functional, it is hypothesized that specific variants increase an individual's susceptibility to specific psychiatric disorders. ${ }^{4,7,8,11}$ Furthermore, as is the case in other fields of medicine (eg, oncology), ${ }^{15}$ genotype can be an important factor in pharmacotherapy. Thus, knowledge of genetics can direct and optimize treatment modalities.

Though this is not a critical review, a search of current studies was performed in PubMed and from other references in the published studies using the terms: 5-HTTLPR, serotonin transporter, major depressive disorder or depression, anxiety, suicide, bipolar disorder, alcoholism or alcohol dependence, nicotine dependence and smoking, post traumatic stress disorder, and attention deficit hyperactivity disorder. Notably, we decided not to include schizophrenia in this review because the broad spectrum of psychopathology presented by this illness was impossible to address in this review.

\section{Anxiety}

The heritability of anxiety-related personality traits is believed to be between $40 \%$ and $60 \%$, but the genes responsible have yet to be identified, and heritability involves multiple genes. ${ }^{4}$ Within the serotonergic treatment model of anxiety, the 5-HTT is a frequent target of anxiolytic pharmacotherapy, ${ }^{16}$ and has been implicated in the pathology of anxiety disorders in human and animal studies. ${ }^{4,6,17-19}$

In research on the association between 5-HTTLPR alleles and personality traits, carriers of $\mathrm{S}$ alleles $(\mathrm{S} / \mathrm{S}$ or $\mathrm{S} / \mathrm{L}$ ) were reported to have higher neuroticism (considered a vulnerability factor for anxiety and depression) scores than L homozygotes (L/L). ${ }^{4}$ Specifically, the $\mathrm{S}$ allele was significantly associated with the Revised-NEO Personality Inventory (NEO-PI-R) neuroticism facet of anxiety $(P=0.027)$ and the Cattell $16 \mathrm{PF}$ personality inventory anxiety factor. ${ }^{4}$ Based on the heritability demonstrated in twin studies, the authors estimated that 5-HTT genotype contributes $3 \%-4 \%$ of total variation and $7 \%-9 \%$ of genetic variance in anxiety-related personality traits. ${ }^{4}$

Given the inherent difficulty and subjectivity in measuring behavior and personality, a more objective association between 5-HTT genotype and anxiety was sought using the endophenotype of amygdala activity, the core of the fear response. ${ }^{6}$ Studies had demonstrated an association between 5-HTT functionality and an abnormal fear response, a condition that is dependent upon the amygdala. ${ }^{6}$ The researchers theorized that functional magnetic resonance imaging measurement of amygdala activity in response to fearful stimuli would allow for more objective conclusions regarding the influence of 5-HTT genotype on fear and anxiety-related behavior. ${ }^{6}$ The results demonstrated that $\mathrm{S}$ carriers had a significantly greater amygdala response than participants with the $\mathrm{L} / \mathrm{L}$ alleles, suggesting that the $\mathrm{S}$ allele is associated with a greater degree of amygdala excitability. ${ }^{6}$ Moreover, the 5-HTT-mediated effect on excitability was specific to the amygdala, because subjects did not exhibit significant differences in excitability of other brain regions, ${ }^{6}$ and is confirmed by others. ${ }^{17,18}$ Increased amygdala activity in $\mathrm{S}$ carriers was reported to be in response to aversive but not pleasurable pictures. ${ }^{17}$ Further, in an event-related functional magnetic resonance imaging study, in addition to amplitude of neural response, 5-HTT genotype also affected connectivity between components of the neural system. ${ }^{18}$

In a meta-analysis of 14 studies and three unpublished data sets, a significant association between the $\mathrm{S}$ allele and heightened amygdala activation was found $(P<0.001)$ and was estimated to account for as much as $10 \%$ of phenotypic variance. ${ }^{19}$ Thus, the increased fear and anxiety-related behavior associated with the S allele may be the result of an exaggerated amygdala response to aversive environmental stimuli, thereby predisposing carriers to stress-related psychiatric disorders. ${ }^{19}$ 
Table I Notable studies reporting the association of the 5-HTTLPR polymorphism to psychopathology

\begin{tabular}{|c|c|c|c|c|}
\hline Psychopathology & Reference & $\mathbf{n}$ & Risk allele & Comment \\
\hline \multirow[t]{7}{*}{ Anxiety } & Lesch et $\mathrm{al}^{4}$ & 505 & $\mathrm{~S}$ & Genotype contributes $3 \%-4 \%$ of total variation and $7 \%-9 \%$ \\
\hline & & & & of genetic variance in anxiety-related personality traits \\
\hline & Hariri et $\mathrm{al}^{6}$ & 28 & $\mathrm{~S}$ & Increased amygdala activity in response to fearful stimuli \\
\hline & Heinz et al ${ }^{17}$ & 29 & $\mathrm{~S}$ & $\begin{array}{l}\text { Increased amygdala activity in response to aversive but not } \\
\text { pleasant pictures }\end{array}$ \\
\hline & Surguladze et al ${ }^{18}$ & 29 & $\mathrm{~S}$ & $\begin{array}{l}\text { Genotype affects amplitude of neural response and } \\
\text { connectivity within the neural system }\end{array}$ \\
\hline & Munafo et al ${ }^{19}$ & NR & $\mathrm{S}$ & $\begin{array}{l}\text { Meta-analysis; heightened amygdala activation; 10\% } \\
\text { of phenotypic variance }\end{array}$ \\
\hline & Munafo et a ${ }^{20}$ & 3872 & NS & $\begin{array}{l}\text { Meta-analysis; no association with two measures of anxiety- } \\
\text { related personality traits; results differ between personality } \\
\text { inventories }\end{array}$ \\
\hline \multirow[t]{15}{*}{ Depression } & Caspi et $\mathrm{al}^{7}$ & 847 & $\mathrm{~S}$ & $\begin{array}{l}\mathrm{G} \times \mathrm{E} \text { interaction with effect of stressful life events on } \\
\text { depression risk; childhood maltreatment predicted adult } \\
\text { depression in } \mathrm{S} \text { carriers only }\end{array}$ \\
\hline & Risch et al' ${ }^{12}$ & 14,250 & NS & $\begin{array}{l}\text { Meta-analysis; no significant association with depression; no } \\
\text { interaction with the effect of stressful life events on the risk } \\
\text { of depression }\end{array}$ \\
\hline & Coplan et $\mathrm{al}^{27}$ & 9 & $\mathrm{~S}$ & $\begin{array}{l}\text { Bonnet macaques; elevated } \mathrm{CRH} \text { in CSF of primate } \mathrm{S} \\
\text { carriers raised under stressful conditions }\end{array}$ \\
\hline & Yu et $\mathrm{a}^{29}$ & 121 & $\mathrm{~L} / \mathrm{L}$ & $\begin{array}{l}\text { Better response to fluoxetine with } L / L \text { genotype; genotype } \\
\text { predicted response; } L \text { homozygotes more likely to be } \\
\text { responders }\end{array}$ \\
\hline & Smeraldi et al ${ }^{30}$ & 102 & $\mathrm{~L}$ & $\mathrm{~L}$ carriers demonstrated a greater response to fluvoxamine \\
\hline & Zanardi et $\mathrm{al}^{33}$ & 60 & $\mathrm{~L} / \mathrm{L}$ & $\begin{array}{l}\text { Dose response: } \mathrm{L} / \mathrm{S} \text { genotype had response to paroxetine } \\
\text { in between } \mathrm{S} \text { and } \mathrm{L} \text { homozygotes }\end{array}$ \\
\hline & Pollock et $\mathrm{al}^{34}$ & 95 & $\mathrm{~L} / \mathrm{L}$ & $\begin{array}{l}\text { No genotype effect on response to nortriptyline; L/L } \\
\text { genotype associated with quicker response to paroxetine }\end{array}$ \\
\hline & Durham et $\mathrm{al}^{35}$ & 206 & $\mathrm{~L} / \mathrm{L}$ & $\begin{array}{l}\text { L/L genotype associated with quicker response to } \\
\text { sertraline }\end{array}$ \\
\hline & Huezo-Diaz et $\mathrm{al}^{37}$ & 795 & $\mathrm{~L}$ & $\begin{array}{l}\text { The effect of 5-HTTLPR on response to escitalopram } \\
\text { response was conditional on gender (males) and modulated } \\
\text { by the rs } 2020933 \text { polymorphism }\end{array}$ \\
\hline & Serretti et $\mathrm{a}^{39}$ & 1435 & $\mathrm{~L} / \mathrm{L}$ & $\begin{array}{l}\text { Meta-analysis; poor response to SSRIs in S carriers; } \mathrm{S} \text { allele- } \\
\text { mediated effect on time-to-response; } \mathrm{L} / \mathrm{L} \text { genotype versus } \\
\text { the } \mathrm{L} / \mathrm{S} \text { and } \mathrm{S} / \mathrm{S} \text { genotypes yielded significant odds ratios for } \\
\text { response rate and response within four weeks }\end{array}$ \\
\hline & Karg et $\mathrm{a}^{26}$ & 40,749 & $\mathrm{~S}$ & Meta-analysis; strong association between the 5-HTTLPR \\
\hline & & & & $\begin{array}{l}\text { S allele and an increased risk of developing depression } \\
\text { under stress. When specific stressors were considered, the } \\
\text { strongest association was with the childhood maltreatment } \\
\text { and the specific medical condition groups }\end{array}$ \\
\hline & Taylor et a $\mathrm{l}^{40}$ & 5408 & NS & The 5-HTTLPR did not predict antidepressant outcome \\
\hline & Lewis et $\mathrm{a}^{36}$ & 258 took citalopram & NS & No influence of 5-HTTLPR as a predictor of depression \\
\hline & & 262 took reboxetine & & outcome \\
\hline \multirow[t]{4}{*}{ Suicidal behavior } & Du et al $\mathrm{a}^{43,44}$ & 55 & $\mathrm{~L}$ & $\begin{array}{l}\text { Completed suicide victims had almost double the frequency } \\
\text { of the } L / L \text { genotype than that of controls }\end{array}$ \\
\hline & Russ et $\mathrm{a}^{45}$ & 102 & NS & No significant difference in allele frequency; significantly \\
\hline & & & & $\begin{array}{l}\text { increased hopelessness and suicidal ideation in patients } \\
\text { homozygous for the } L \text { allele }\end{array}$ \\
\hline & Anguelova et $\mathrm{a}^{46}$ & 2539 & $\mathrm{~S}$ & $\begin{array}{l}\text { Meta-analysis; association attributable to studies } \\
\text { investigating suicide attempters }\end{array}$ \\
\hline \multirow[t]{3}{*}{ Bipolar disorder } & Cho et $\mathrm{a}^{48}$ & $4296+587$ trios & $\mathrm{S}$ & $\begin{array}{l}\text { Meta-analysis, population-based and family-based; increased } \\
\text { susceptibility to BPD }\end{array}$ \\
\hline & Anguelova et $\mathrm{a}^{49}$ & 3467 & $\mathrm{~S}$ & Meta-analysis; increased susceptibility to BPD \\
\hline & Rotondo et al ${ }^{50}$ & 349 & $\mathrm{~S}$ & $\begin{array}{l}\text { Association significant only for BPD without comorbid } \\
\text { panic disorder versus BPD with comorbid panic disorder }\end{array}$ \\
\hline
\end{tabular}


Table I (Continued)

\begin{tabular}{|c|c|c|c|c|}
\hline Psychopathology & Reference & $\mathbf{n}$ & Risk allele & Comment \\
\hline & Mundo et $\mathrm{al}^{52}$ & 56 & $\mathrm{~S}$ & Association between $\mathrm{S}$ allele and manic/hypomanic episodes \\
\hline & & & & in BPD patients treated with antidepressants \\
\hline \multirow[t]{7}{*}{ PTSD } & Lee et $\mathrm{al}^{55}$ & 297 & S & Significantly higher frequency of the S-homozygous \\
\hline & & & & genotype in patients with PTSD \\
\hline & Wang et $\mathrm{al}^{56}$ & 388 & $S^{\prime} / S^{\prime}$ & The $S^{\prime}$-homozygous genotype was associated with the \\
\hline & & & & $\begin{array}{l}\text { PTSD severity score in the } 228 \text { participants who had } \\
\text { combat severity data }\end{array}$ \\
\hline & Xie et $\mathrm{al}^{57}$ & 1252 & S & $\begin{array}{l}\text { S carriers have increased risk of PTSD in response to } \\
\text { trauma as a child and adult }\end{array}$ \\
\hline & Mushtaq et $\mathrm{al}^{59}$ & 330 & $\mathrm{~L} / \mathrm{L}$ & $\begin{array}{l}\text { L-homozygous is associated with greater responsiveness of } \\
\text { PTSD to sertraline ( } 100 \mathrm{mg} / \text { day) with lower drop out due } \\
\text { to adverse events }\end{array}$ \\
\hline & Grabe et $\mathrm{al}^{60}$ & 3045 & $\mathrm{~L}_{\mathrm{A}}$ & $\begin{array}{l}\text { Gene-dose effect; interaction between the } \mathrm{L}_{\mathrm{A}} \text { allele and } \\
\text { number of traumatic life events }\end{array}$ \\
\hline \multirow[t]{12}{*}{ Alcohol dependence } & Kweon et $\mathrm{a}^{64}$ & 346 & $\mathrm{~L}$ & $\begin{array}{l}\text { Increased risk of alcoholism; gene-dose effect; younger age } \\
\text { of onset; associated with family history of } A D\end{array}$ \\
\hline & McHugh et $\mathrm{al}^{66}$ & 8050 & S & Meta-analysis; greater effect seen in S homozygotes \\
\hline & Ait-Daoud et $a^{67}$ & 34 & $\mathrm{~L}$ & $\begin{array}{l}\mathrm{L} \text { carriers had higher craving than } \mathrm{S} / \mathrm{S} \text {; Craving in } \mathrm{L} \text { carriers } \\
\text { increased with an earlier age of onset of problem drinking }\end{array}$ \\
\hline & Feinn et $a^{69}$ & 5814 & S & $\begin{array}{l}\text { S allele significantly associated with } A D \text {; Greatest } \\
\text { association between } S \text { allele and comorbid psychiatric } \\
\text { condition, early-onset or more severe } A D \text { subtype }\end{array}$ \\
\hline & Enoch et $\mathrm{al}^{70}$ & 547 & NS & $\begin{array}{l}\text { No significant association for } A D \text { only; Frequency of } S \text { allele } \\
\text { significantly increased in patients with } A D \text { and comorbid } \\
\text { drug dependence }\end{array}$ \\
\hline & Matsushita et $\mathrm{al}^{8}$ & 967 & $\mathrm{~S} / \mathrm{S}$ & S-homozygous genotype associated with binge drinking \\
\hline & Kranzler et $\mathrm{al}^{75}$ & 101 & TX & Increased alcohol consumption in EOAs with fluoxetine \\
\hline & Pettinati et $\mathrm{al}^{76}$ & 100 & NA & $\begin{array}{l}\text { Increased alcohol consumption in EOAs with sertraline; } \\
\text { decreased consumption in LOAs }\end{array}$ \\
\hline & Kranzler et al ${ }^{77}$ & 134 & $L^{\prime} / L^{\prime}$ & $\begin{array}{l}\text { In } L_{A} / L_{A}\left(L^{\prime} / L^{\prime}\right) \text { homozygotes, the effects of medication } \\
\text { group varied by age of onset. LOAs with the } L^{\prime} / L^{\prime} \text { alleles } \\
\text { had fewer drinking and heavy drinking days with sertraline; } \\
\text { EOAs had fewer drinking and heavy drinking days with } \\
\text { placebo }\end{array}$ \\
\hline & Johnson et $\mathrm{al}^{78}$ & 271 & NR & $\begin{array}{l}\text { Treatment with ondansetron increased the number and } \\
\text { percentage of days abstinent in patients with EOA but not } \\
\text { LOA }\end{array}$ \\
\hline & Kenna et $\mathrm{al}^{72}$ & 15 & $\mathrm{~L} / \mathrm{L}$ & $\begin{array}{l}\text { L homozygotes receiving ondansetron had significantly } \\
\text { fewer DDD than patients receiving sertraline }\end{array}$ \\
\hline & Johnson et al ${ }^{82}$ & 283 & $\mathrm{~L} / \mathrm{L}$ & $\begin{array}{l}\text { L homozygotes who received ondansetron reported fewer } \\
\text { mean drinks per drinking day and a higher percentage of } \\
\text { days abstinent }\end{array}$ \\
\hline $\begin{array}{l}\text { Nicotine } \\
\text { dependence }\end{array}$ & Kremer et $\mathrm{al}^{87}$ & 730 & $\mathrm{~L}$ & $\begin{array}{l}\text { Frequency significantly increased in both current and past } \\
\text { smokers compared with nonsmoker controls }\end{array}$ \\
\hline \multirow[t]{4}{*}{ ADHD } & Thakur et al ${ }^{90}$ & 157 & $\mathrm{~L}_{\mathrm{A}}$ & $\begin{array}{l}\mathrm{L}_{\mathrm{A}} \text { carriers responded significantly better to } \\
\text { methylphenidate than placebo; patients without a } \mathrm{L}_{\mathrm{A}} \text { allele } \\
\text { did not exhibit a significantly better response compared } \\
\text { with placebo }\end{array}$ \\
\hline & Seegar et $\mathrm{a}^{91}$ & 243 & $\mathrm{~L} / \mathrm{L}$ & $\begin{array}{l}\text { Frequency of L-homozygous genotype significantly } \\
\text { increased in patients with hyperkinetic disorder both with } \\
\text { and without conduct disorder }\end{array}$ \\
\hline & Retz et $\mathrm{al}^{93}$ & 169 & $\mathrm{~L} / \mathrm{L}$ & L homozygotes scored significantly higher on the WURS. \\
\hline & Zoroğlu et al ${ }^{94}$ & 199 & L & $\begin{array}{l}\text { Frequency of S-homozygous genotype significantly lower in } \\
\text { patients with ADHD }\end{array}$ \\
\hline
\end{tabular}

Abbreviations: AD, alcohol dependence; ADHD, attention deficit hyperactivity disorder; BPD, bipolar disorder; $C R H$, corticotrophin-releasing hormone; CSF, cerebrospinal fluid; DDD, drinks per drinking day; EOA, early-onset alcoholism; G $\times$ E, gene $\times$ environment; L, long 5-HTTLPR allele; LOA, late-onset alcoholism; NR, not reported; NS, not significant; PTSD, post-traumatic stress disorder; S. short 5-HTTLPR allele; SSRI, selective serotonin reuptake inhibitor; WURS, Wender Utah Rating Scale; 5-HTT, serotonin transporter. 
While findings regarding the association between the 5-HTTLPR and amygdala response have been rather consistent, some studies assessing the association between 5-HTTLPR and anxiety traits directly have produced mixed results. For example, Munafò et a ${ }^{20}$ confirmed data by WillisOwen et $\mathrm{al}^{21}$ that reported no association between 5-HTTLPR polymorphism and two measures of anxiety-related personality traits, ie, harm avoidance and Eysenck Personality Questionnaire (EPQ) neuroticism. ${ }^{20}$ While a large number of small studies in support of an association exist, these studies primarily used the NEO-PI-R measure of neuroticism. And while the combined EPQ and NEO-PI-R measures of neuroticism were significant for an association with the $\mathrm{S}$ allele, stratification by neuroticism measurement instrument delineated only studies utilizing the NEO-PI-R to remain significant. ${ }^{20}$ The authors interpreted this as suggestive of a variation in an anxiety-related personality trait defined by the NEO-PI-R instrument being influenced by the 5-HTTLPR. ${ }^{20}$

In summary, the bulk of the evidence suggests that increased serotonergic neurotransmission is associated with the $\mathrm{S}$ allele, which may be anxiogenic, as demonstrated by an enhanced amygdala response to anxiety. By contrast, studies of the direct association between 5-HTT genotype and anxiety traits have produced mixed results depending on the personality inventory utilized, suggesting that larger and more fully powered studies are necessary to provide more definitive evidence of this association.

\section{Depression}

While the annual prevalence of depression as defined by the Diagnostic and Statistical Manual IV-TR (DSM-IV-TR) ${ }^{22}$ criteria is estimated to be $3.2 \%$, the heritability of depression is thought to be $31 \%-42 \%{ }^{23}$ In 2003 , a gene $\times$ environment $(\mathrm{G} \times \mathrm{E})$ hypothesis was proposed, suggesting that because an association between 5-HTT genotype and response to stress in animals and humans had been demonstrated, and that stressful life events are known to affect the onset and course of depression, ${ }^{24}$ it was therefore logical to conclude that the 5-HTT genotype could contribute to the development of depression. ${ }^{7}$ These researchers sought to determine if 5-HTT genotype altered the serotonergic response to stress, thereby predisposing participants to a greater influence of stressful life events on depression. ${ }^{7}$ Caspi et al demonstrated a positive association between the number of stressful life events and the probability of depression that was statistically stronger in S carriers than L homozygotes. ${ }^{7}$ This association suggested that among participants who experienced more than four stressful life events, $\mathrm{S}$ carriers were twice as likely as L homozygotes to develop depression. The authors also reported that maltreatment as a child predicted depression as an adult in S carriers only. While the researchers noted that their results did not prove a direct association between 5-HTT genotype and depression, they concluded that S carriers were more likely to develop depression in response to stressful life events. ${ }^{7}$

In order to examine the association between 5-HTT genotype and depression, Risch et a $1^{12}$ performed a metaanalysis of 14 replication studies $(n=14,250)$ and found that many of the trials failed to reproduce the results reported by Caspi et al. ${ }^{7}$ Furthermore, other studies reviewed were only able to replicate the results partially or even produced contradictory results. ${ }^{12}$ While this meta-analysis affirmed the association between number of stressful life events and depression, the study failed to find a significant association between 5-HTTLPR genotype and depression. ${ }^{12}$ Moreover, Risch et al ${ }^{12}$ failed to find a significant interaction between genotype and the effect of stressful life events on the risk of depression in men alone, women alone, or both genders combined. ${ }^{12}$ To test the $\mathrm{G} \times \mathrm{E}$ hypothesis more directly, the authors stratified the sample by number of stressful life events. ${ }^{12}$ Contrary to the results previously reported, ${ }^{7}$ they discovered no significant difference in allele frequency between those with and without depression, ${ }^{12}$ and noted that the largest increase in $\mathrm{S}$ allele frequency occurred for one stressful life event, ${ }^{12}$ inconsistent with the greater than four stressful life events as previously reported. ${ }^{7}$ Munafò et $\mathrm{al}^{25}$ performed a similar $\mathrm{G} \times \mathrm{E}$ meta-analysis with five of 33 studies and concluded that the moderating effect of 5-HTTLPR on depression or interaction with significant life events was small or even negligible.

In contrast, a 2011 meta-analysis by Karg et a ${ }^{26}$ noted how, based on their a priori criteria, previous meta-analytic studies $^{12,25}$ of the interaction between 5-HTTLPR polymorphism and stress in the development of depression excluded most publications. Karg et al included 54 of 56 studies by using a different data extraction approach. ${ }^{26}$ The main results of this meta-analysis demonstrated a strong association between the 5-HTTLPR S allele and an increased risk of developing depression under stress. When the analysis was conducted considering specific stressors, the strongest association was with childhood maltreatment and the specific medical condition groups. Interestingly, Karg et $\mathrm{al}^{26} \mathrm{did}$ not find such associations when they restricted the analysis to studies included in the previous meta-analyses. ${ }^{12,25}$ This suggests that the differences in results can be explained 
with the significantly different number of studies included in the analysis. ${ }^{26}$

Caspi et $a l^{5}$ reviewed several lines of evidence examining the association between 5-HTTLPR and depression up until mid 2009 and assessed the $\mathrm{G} \times \mathrm{E}$ interaction and 5-HTT stress sensitivity hypothesis specifically. ${ }^{5}$ In analyzing the differences between studies producing positive and negative results, the authors suggest that the varying results may be related to the methodology by which stressful life events are assessed. ${ }^{5}$ Specifically, they concluded that: most of the negative studies utilized self-reported measures of stress rather than objective measures such as inperson interviews; studies that assessed specific clearly operationalized stressors, rather than generalized number of stressors, consistently find that the $\mathrm{S}$ allele moderates the association between child maltreatment and depression, most likely due to more robust internal validity; and studies that focused on a specific stressor of childhood maltreatment rather than stressful or adverse life events, consistently demonstrated positive findings. ${ }^{5}$

Examining more complex interactions, Coplan et al in macaques $^{27}$ and Ressler et al in humans ${ }^{28}$ tested the $\mathrm{G} \times \mathrm{E}$ interactions between 5-HTTLPR and corticotropin-releasing hormone polymorphism (CRHR1) on childhood abuse and depressive symptoms. Coplan et al reported that corticotropin-releasing hormone concentrations were elevated in macaques raised in a primate model of early-life stress specifically in $\mathrm{S} / \mathrm{S}$ and $\mathrm{S} / \mathrm{L}$ genotype groups. ${ }^{27}$ Ressler et al reported that the $S$ allele in their study $(n=856)$ interacted with the CRHR1 haplotypes and child abuse that predicted current depressive symptoms. These researchers concluded that their data suggest that the $G \times E$ interactions predict depressive symptoms may be differentially sensitive to levels of childhood trauma. ${ }^{28}$

While the exact nature of the association between 5-HTT genotype and depression continues to be a complex area of research, what is established is that the 5-HTT genotype can significantly influence response to antidepressant medications. For example, a study was performed in China with 121 patients diagnosed with major depressive disorder and treated with the selective serotonin reuptake inhibitor (SSRI) fluoxetine (mean $29.4 \pm 10.4 \mathrm{mg} /$ day) demonstrated that subjects homozygous for the $\mathrm{L}$ allele had a significantly greater decrease in their Hamilton Depression Rating Scale (HAM-D) score than subjects who carried the S allele. ${ }^{29}$ While decreases were significantly greater in $\mathrm{L} / \mathrm{L}$ participants in the measures of total and core HAM-D scores, of note is that reductions in psychic anxiety and somatic anxiety were also significant, while differences in the measures of sleep, activity, and delusion were not. ${ }^{29}$ This group also demonstrated that participants with the $\mathrm{L} / \mathrm{L}$ genotype were more likely to be responders, and noted that these results were consistent with earlier studies conducted in Western populations. ${ }^{30-32} \mathrm{Yu}$ et al concluded that the 5-HTTLPR was responsible for $5.1 \%$ of variation in SSRI response and suggested an additive effect with other polymorphisms, such as the tryptophan hydrolase (involved in 5-HT biosynthesis) polymorphism..$^{29}$

A study performed in a Caucasian population comparing antidepressant response of $\mathrm{L} / \mathrm{S}$ and $\mathrm{L} / \mathrm{L}$ to S-homozygous variants demonstrated that carriers of the $\mathrm{L}$ allele (ie, $\mathrm{L} / \mathrm{L}$ and $\mathrm{L} / \mathrm{S}$ ) showed a greater response to fluvoxamine $300 \mathrm{mg} /$ day than $\mathrm{S}$ homozygotes. ${ }^{30}$ However, this result may also differ by ethnic population. For example, a study performed in 66 Japanese patients with major depressive disorder reported that patients with the $\mathrm{S}$ allele were more responsive (though not significantly so) to $200 \mathrm{mg}$ a day of fluvoxamine. ${ }^{31}$ Additionally, in a study of 120 Korean patients with major depressive disorder (and 252 controls) who received fluoxetine or paroxetine similarly did not report that the $\mathrm{L} / \mathrm{L}$ 5-HTTLPR was associated with response to SSRIs, though it should be noted that, compared with European American populations, the allele frequency of S variant 5-HTTLPR in the Korean population, like the Japanese, was much higher..$^{32}$ Further studies of these discrepancies in a variety of ethnic populations are necessary.

A study of inpatients with the $\mathrm{L} / \mathrm{S}$ genotype had a response to $40 \mathrm{mg}$ daily of the SSRI paroxetine somewhere in between that of $\mathrm{S}$ and L homozygotes, suggesting a possible genedose effect. ${ }^{33}$ By contrast, the 5-HTT genotype was shown to have no effect on treatment outcome in patients treated with the tricyclic antidepressant nortriptyline (plasma doses $50-150 \mathrm{ng} / \mathrm{mL}$ ), but $\mathrm{L} / \mathrm{L}$ patients treated with paroxetine $30 \mathrm{mg} /$ day had significant reductions in HAM-D scores from baseline, suggesting that the genotype effect on antidepressant response may be unique to treatment with SSRIs. ${ }^{34}$ Additionally, the L/L genotype was associated with a quicker response to the SSRI paroxetine compared with $\mathrm{S}$ carriers,${ }^{34}$ a finding confirmed with the SSRI sertraline $(50-100 \mathrm{mg} /$ day $)$, in an elderly Caucasian sample $(\mathrm{n}=206)$ suggesting perhaps a SSRI class-wide effect of genotype on speed of antidepressant response. ${ }^{35}$ On the other hand, Lewis et al in a European study of 258 patients taking citalopram and 262 taking reboxetine and meeting the criteria for a depressive episode reported no evidence to support the 5-HTTLPR polymorphism as a predictive tool to predict response to antidepressants in patients with depression. ${ }^{36}$ 
Examining the association between 5-HTLPR and SSRI response, Huezo-Diaz et al demonstrated that gender moderated the outcome of treatment with escitalopram $10-30 \mathrm{mg} /$ day ${ }^{37}$ The study yielded a result in the hypothesized direction, in that participants with the $\mathrm{S} / \mathrm{S}$ genotype who had received escitalopram had significantly poorer outcomes compared with $\mathrm{L}$ carriers. ${ }^{37}$ When stratified by gender, the association was significant in men but not in women and the authors hypothesized that this gender effect was mediated by the affect of ovarian hormones on serotonergic function, ${ }^{37}$ although ovarian hormones were not assessed directly in this sample (eg, before and after treatment with escitalopram). As a result of their research, Huezo-Diaz et al proposed that an additional polymorphism, single nucleotide polymorphism rs2020933 located in the first intron of the SLC6A4 gene, ${ }^{37}$ and subsequent research by Keers et $\mathrm{al}^{38}$ examining the significant interaction between 5-HTTLPR and stressful life events, predicted a response to escitalopram, but not to nortriptyline, and may play significant roles in moderating and predicting response to SSRI antidepressants.

A meta-analysis performed by Serretti et al assessed the remission rate, response rate, and response within the first four-week period of treatment with SSRIs. ${ }^{39}$ In this metaanalysis of 15 studies with 1435 patients reporting various types of depression (eg, major depressive disorder, bipolar disorder), patients with $\mathrm{S} / \mathrm{S}$ alleles took longer to respond and were less likely to achieve remission. Pooled analysis of $\mathrm{L} / \mathrm{L}$ and $\mathrm{L} / \mathrm{S}$ genotypes versus the $\mathrm{S} / \mathrm{S}$ genotype yielded a significant odds ratio (OR) for remission rate for the $\mathrm{S} / \mathrm{S}$ genotype; while the analysis of the $\mathrm{L} / \mathrm{L}$ genotype versus the $\mathrm{L} / \mathrm{S}$ and $\mathrm{S} / \mathrm{S}$ genotypes yielded significant $\mathrm{OR}$ for response rate and response within four weeks, confirming a significant association of the L variant of the 5-HTTLPR with a better response to SSRIs. ${ }^{39}$

Alternately, a more recent meta-analysis was performed to clarify the effect of 5-HTTLPR on SSRI response and rate of remission in 5408 patients with major depressive disorder across 28 studies ${ }^{40}$ No statistically significant effect of transporter promoter length polymorphism on rates of antidepressant response was seen. While the authors reported a weak effect of biallelic polymorphism on remission, a number of factors, like publication bias or lack of reporting of the remission outcomes, were hypothesized as additional factors to consider. ${ }^{40}$

The results of studies assessing the association between 5-HTTLPR and depression are inconsistent. Many researchers report an association between 5-HTTLPR and antidepressant response and that the homozygous $\mathrm{L}$ alleles confer a better response to SSRIs than the homozygous or heterozygous $\mathrm{S}$ alleles. ${ }^{29,30,33-35,37-39}$ While this finding, as determined by post hoc analyses, may represent a promising determinant for personalization of antidepressant therapy, it should be noted that the strength of this association may vary by population, ${ }^{31,32}$ and is not consistently reported. ${ }^{36,40}$ Before a priori genotyping can become a reality, measurement of the association and effect size of other genes affecting antidepressant response is also required so as to form a complete genotypic picture of the patient. Additionally, there must be an effort to standardize assessments such that data and diagnoses can be meaningfully compared across studies. Also, more research is needed across cultural populations before concluding that the $\mathrm{S}$ allele, which is theorized to increase a carrier's predisposition to depression, is associated with poorer response to SSRIs in only certain populations, certainly a finding which has significant implications for the future development of antidepressant medications. ${ }^{41}$

\section{Suicidal behavior}

Though only a proportion of patients diagnosed with major depressive disorder make a suicide attempt, this association is independent of depression severity, ${ }^{42}$ leading to the hypothesis that there are other risk factors for suicidal behavior, including a genetic predisposition involving the 5-HTTLPR ${ }^{43}$ For example, Du et al provided evidence for this association, reporting that depressed suicide victims had a significantly higher frequency of the $\mathrm{L}$ allele than control subjects of the same ethnicity. ${ }^{43}$ The evidence also suggests that depressed suicide victims had almost double the frequency of the $\mathrm{L} / \mathrm{L}$ genotype than that of controls ( $48.6 \%$ versus $26.2 \%$ ), yielding a significant OR of $2.1 .^{44}$

However, in contrast, other studies report no direct or even contrary associations between 5-HTT genotypes and suicidal behavior. For example, while allele frequencies did not differ between suicidal inpatients and controls, inpatients who had the L/L genotype had significantly increased hopelessness and suicidal ideation. ${ }^{45}$ Moreover, though a meta-analysis of 12 studies $(n=2539)$ reported an association between 5-HTT genotype and suicide, the $\mathrm{S}$ allele but not the $\mathrm{L}$ allele was positively associated with suicidal behavior. ${ }^{46}$ Notably, when the researchers included studies that were stratified by type of suicidal behavior, the association was attributable to studies investigating suicide attempters versus completers. ${ }^{46}$ The heterogeneity of these findings therefore suggests that suicidal ideation, attempted suicide, and completed suicide may represent distinct yet overlapping phenotypes within the broader category of suicidal behavior. ${ }^{44}$ 


\section{Bipolar disorder}

While the lifetime prevalence of bipolar disorder is estimated to be about $1 \%$, relatives of patients with bipolar disorder have significantly greater susceptibility to the disorder. ${ }^{47}$ Specifically, monozygotic twins and first-degree relatives have a lifetime risk of $40 \%-70 \%$ and $5 \%-10 \%$, respectively, versus a lifetime risk of $0.5 \%-1.5 \%$ in unrelated individuals. ${ }^{47}$ Candidate gene studies have primarily investigated the genes that code for the neurotransmitter systems targeted by pharmaceutical agents employed in the management of bipolar disorder; consequently, 5-HTT has been implicated through its regulatory role in 5-HT neurotransmission. ${ }^{47}$

A meta-analysis of 23 studies assessed the association between 5-HTTLPR and bipolar disorder, and included both family and population-based studies. ${ }^{48}$ The $\mathrm{S}$ allele was significantly associated with increased susceptibility to bipolar disorder. ${ }^{48} \mathrm{~A}$ significant OR for another polymorphism, ie, the intron 2 variable numbers of tandem repeats (VNTR) polymorphism, was also reported (OR: 1.12; 95\% confidence interval [CI]: $1.02-1.22) .^{48}$ These findings for both 5-HTTLPR and intron 2 VNTR were supported by others who reported small but significant OR of 1.14 (95\% CI: 1.03-1.26) and 1.18 (95\% CI: 1.05-1.32), respectively. ${ }^{49}$ Given the heterogeneity of bipolar disorder, researchers ${ }^{44}$ have interpreted the small effect sizes as suggestive of either a polygenic model for bipolar disorder susceptibility or a $\mathrm{G} \times \mathrm{E}$ interaction similar to that proposed for unipolar depression. ${ }^{?}$

Rotondo et al sought to determine if comorbid panic disorder had an effect on the association between patients with bipolar disorder and 5-HTTLPR genotype. ${ }^{50}$ While a significant increase in $\mathrm{S}$ allele frequency was discovered in all patients with bipolar disorder, grouping by the presence or absence of comorbid panic disorder implicated genetically distinct subtypes of bipolar disorder. ${ }^{50}$ Specifically, subjects with bipolar disorder but without comorbid panic disorder, had a significantly increased frequency of the $\mathrm{S}$ allele compared with healthy subjects $(P=0.008)$, while patients with comorbid bipolar disorder and panic disorder did not have any significant difference in allele frequency compared with healthy controls. ${ }^{50}$ This suggests that the absence or presence of comorbid panic disorder in patients with bipolar disorder may represent unique bipolar disorder subtypes with different genetic susceptibilities. ${ }^{50}$

Some patients with bipolar disorder taking antidepressants without a concurrent mood stabilizer can experience antidepressant-induced mania $;{ }^{51}$ this effect is sometimes referred to as type 3 bipolar disorder. ${ }^{51}$ Consequently, a genotype-mediated effect on antidepressant response may place individuals at a higher risk for this adverse event. As discussed in the section on depression, studies including patients with bipolar disorder have demonstrated that the 5-HTT genotype can affect SSRI treatment outcomes, as measured by change on depression rating scales. ${ }^{38}$ Hence, determination of genotype effect on risk of antidepressantinduced mania is critical to management of bipolar disorder. However, while one group ${ }^{52}$ reported a significant association between the $\mathrm{S}$ allele and manic or hypomanic episodes in bipolar disorder patients treated with proserotonergic antidepressants $(P<0.001)$, other studies have failed to find any significant association. ${ }^{53,54}$

\section{Post-traumatic stress disorder}

Although post-traumatic stress disorder inherently requires exposure to a traumatic event, not all individuals who experience such an event develop DSM-IV-TR-diagnosed post-traumatic stress disorder. ${ }^{5-57}$ This is evident in the stark contrast between the $40 \%-80 \%$ lifetime prevalence of exposure to traumatic events and the lifetime incidence of post-traumatic stress disorder in one of 12 adults. ${ }^{52-54}$ This distinction suggests that individuals who develop post-traumatic stress disorder in response to exposure to a traumatic event may have a predisposing factor not present in perhaps more resilient unaffected individuals.

In order to delineate such predisposing factors, the effect of 5-HTTLPR on susceptibility to post-traumatic stress disorder was assessed. ${ }^{55}$ Patients with post-traumatic stress disorder had a significantly higher frequency of the $\mathrm{S} / \mathrm{S}$ genotype compared with unaffected controls. ${ }^{55}$ While this study demonstrated a significant association between 5-HTTLPR genotype and susceptibility to post-traumatic stress disorder, unaffected controls did not have a history of trauma exposure, and consequently, assessment of 5-HTTLPR as a predisposing factor was not possible. However, in a more recent study, Wang et al confirmed that the $\mathrm{S} / \mathrm{S}$ genotype was a significant predisposing factor $(P=0.03)$ for the development of posttraumatic stress disorder in a sample of 388 combat veterans after trauma exposure. ${ }^{56}$

Similar to the $\mathrm{G} \times \mathrm{E}$ effect proposed for depression,? the influence of a $G \times E$ effect on the development and treatment of post-traumatic stress disorder in individuals exposed to traumatic events as a child or adult have also been examined. For example, Xie et a ${ }^{57}$ demonstrated that while the 5-HTTLPR genotype alone was not significantly associated with post-traumatic stress disorder, S carriers were at an increased risk of post-traumatic stress disorder in 
response to trauma as a child and as an adult. ${ }^{57}$ Moreover, the effect size was even greater for individuals with posttraumatic stress disorder who experienced traumatic events both as a child and as an adult. ${ }^{57}$ In addition, the number of traumatic life events, especially as a child, was also seen to increase the predisposition to post-traumatic stress disorder in $\mathrm{S}$ carriers. ${ }^{53}$ These results were also confirmed in a study of 5-HTTLPR, childhood trauma, and cognition in patients with psychotic disorders. ${ }^{58}$ There was a significant interaction across cognitive domains, such that $\mathrm{S} / \mathrm{S}$ carriers exposed to high levels of childhood trauma had significantly poorer cognitive functioning than all other groups. Additionally, consistent with the research on depression, in a study of 330 outpatients diagnosed with post-traumatic stress disorder and treated with sertraline $100 \mathrm{mg} /$ day, Mushtaq et al reported a significant response to sertraline treatment for the group with the L/L allele only. ${ }^{59}$ As also noted for depression, ${ }^{29,30,33,34}$ there was a nonresponse to SSRI treatment for those with either the $\mathrm{S} / \mathrm{S}$ or $\mathrm{S} / \mathrm{L}$ alleles.

However, other researchers have indeed reported conflicting results. For example, Grabe et al reported a significant association between the high activity $\mathrm{L}_{\mathrm{A}}$-homozygous genotype and post-traumatic stress disorder, and noted a genedose effect as the crude proportion of post-traumatic stress disorder increased in the study groups from $2 \%$ (zero), $4 \%$ (one), to 6\% (two) $\mathrm{L}_{\mathrm{A}}$ alleles. ${ }^{60}$ Moreover, no association was reported for the low-activity $\mathrm{L}_{\mathrm{G}}$ allele. In addition, among $\mathrm{L}_{\mathrm{A}}$ carriers, the increased post-traumatic stress disorder risk was reported to be even greater in subjects who experienced three or more traumatic events $(12.8 \%)$ than those who had not $(3.9 \%)$, suggesting an interaction between the $\mathrm{L}_{\mathrm{A}}$ allele and number of traumatic life events. ${ }^{57}$ While these authors ${ }^{60}$ note that the results are inconsistent with some previous studies, ${ }^{55,61}$ they also suggest that low statistical power and a failure to differentiate the $\mathrm{L}$ allele subtypes (ie, $\mathrm{L}_{\mathrm{A}}$ and $\mathrm{L}_{\mathrm{G}}$ ) may explain the varying results of these other studies.

\section{Alcohol dependence}

Alcohol dependence has 50\%-60\% heritability, and it is estimated that as much as $40 \%$ of variance in alcohol dependence may be attributable to genetic factors. ${ }^{62-64}$ Given the interplay of the 5-HT and dopamine systems and its role in novelty seeking and reward, 5-HT regulatory genes have been suggested as candidates for vulnerability to alcohol dependence and, of these, 5-HTTLPR has received considerable attention. ${ }^{64-66}$ While most studies demonstrate an association between 5-HTTLPR and alcohol dependence, the association with specific alleles is inconsistent, varying based on alcohol subtype, type of drinking behavior, ethnicity, comorbid diagnoses, or age of onset.

For example, in a study of inpatients with alcohol dependence in Korea, the association between the 5-HTTLPR and alcohol dependence was assessed. ${ }^{64} \mathrm{~L}$ carriers had a significantly increased risk of alcohol dependence and the researchers also noted a gene-dose effect. The gene-dose effect suggested that inpatients with $\mathrm{L} / \mathrm{L}$ alleles had an even greater risk of alcoholism compared with those having heterozygous variants. In addition, it was reported that patients with a family history of alcohol dependence had a significantly higher frequency of the L allele and L-carrying patients with alcohol dependence had a significantly younger age of onset. ${ }^{64}$ Others have also demonstrated that reduced functional 5-HTT uptake in L carriers, not S/S carriers, is due to the effect of alcohol on 5-HTT gene expression and that 5-HTT expression varies with current and lifetime alcohol consumption in people with the L genotype alone, resulting in more severe and chronic drinking. ${ }^{65}$

In 34 Hispanic individuals with alcohol dependence, a $\mathrm{G} \times \mathrm{E}$ interaction hypothesis was tested, ie, those with the $\mathrm{L} / \mathrm{L}$ or L/S genotype would have higher craving for alcohol due to lower 5-HT neurotransmission than those with the S/S genotype.${ }^{67}$ Also hypothesized was that acute peripheral depletion of tryptophan, while reducing 5-HT function, at the same time may decrease autoinhibition of 5-HT neuronal firing, transiently increasing 5-HT neurotransmission, leading to lowered alcohol craving for individuals with the L genotype. And while a significant main effect was reported of genotype and alcohol cue, as well as an interaction among genotype, age of onset of problem drinking, and tryptophan depletion, $\mathrm{L}$ carriers reported higher craving for alcohol. This effect decreased as hypothesized under tryptophan depletion. ${ }^{64}$ In addition, craving in L carriers also increased, with an earlier age of onset of problem drinking, an effect opposite to that reported by individuals with the $\mathrm{S} / \mathrm{S}$ genotype. ${ }^{67}$

While the association between alcohol dependence and 5-HTTLPR is significant, it must also be kept in mind that 5-HTTLPR frequencies are also known to vary dramatically with ethnicity, ${ }^{64}$ and a meta-analysis with a broader ethnic sample yielded conflicting results. ${ }^{66}$ Notably, a meta-analysis of 22 studies $(n=8050)$ was conducted to investigate the association between 5-HTTLPR and a clinical diagnosis of alcohol dependence. A significant association between alcohol dependence and the $\mathrm{S}$ allele was reported, with an even greater effect seen in those with the $\mathrm{S} / \mathrm{S}$ genotype. However, a possible publication bias was noted $(P<0.05)$, with a greater number of studies reporting no association 
being published in recent years. It was also reported that the study size influenced the reported effect size, with larger studies finding relatively smaller effects. ${ }^{66}$

Other studies that have examined the relationship between alcohol dependence and 5-HTTLPR, have discovered the association to be the strongest among alcohol-dependent individuals with co-occurring diagnoses, age of onset, or drinking subtype. For example, a study of heavy drinking young adults by Tartter and Ray ${ }^{68}$ demonstrated that heavier alcohol use was associated with depressive symptoms in $\mathrm{L} / \mathrm{L}$ homozygotes but not among $\mathrm{S}$ carriers. These results also indicated a main effect of 5-HTTLPR genotype such that $\mathrm{L}$ allele homozygotes had significantly more alcohol problems and more drinks consumed over a 30-day period than $\mathrm{S}$ allele carriers. This study offers support for the $\mathrm{L}$ allele as a risk for alcohol abuse problems when depressive symptoms are present. However, these results contrast with those reported by Feinn et al from a meta-analysis of data from 17 studies consisting of 3489 individuals with alcohol dependence and 2325 controls. In this study, the frequency of the $\mathrm{S}$ allele was significantly associated with alcohol dependence. ${ }^{69}$ Additionally, the association was even greater among individuals with alcohol dependence and either a comorbid psychiatric condition or an early-onset or more severe subtype of alcohol dependence. ${ }^{69}$

In recent research, the frequency of the $\mathrm{S}$ allele was reported to be significantly increased in patients with alcohol dependence and comorbid drug dependence. ${ }^{70}$ Notably, no significant association was reported for patients with alcohol dependence alone. ${ }^{66}$ Additionally, though no significant difference in allele frequencies between patients with alcohol dependence and controls was reported, the frequency of the S-homozygous genotype was significantly greater in binge-drinking patients with alcohol dependence. ${ }^{8}$ This finding was similarly reported by others ${ }^{65,71}$ who demonstrated that $\mathrm{S} / \mathrm{S}$ subjects tended to binge drink and were younger than $\mathrm{L} / \mathrm{L}$ subjects, together suggesting a subgroup of patients with alcohol dependence genetically predisposed to binging behavior. ${ }^{8,65,72}$

While the variation in results regarding the association between 5-HTTLPR and alcohol dependence likely reflects the underlying heterogeneity of alcohol dependence itself, the 5-HTTLPR genotype has been investigated and used to target pharmacotherapy for relatively homogenous subgroups. It was proposed for example that genotypic differences exist between two subtypes of patients with alcohol dependence, ie, type A alcoholics with late-onset alcoholism starting after 25 years of age and type B alcoholics with early-onset alcoholism starting at 25 years of age or younger. ${ }^{3,72-74}$ Among patients with alcohol dependence, the $\mathrm{S} / \mathrm{S}$ and $\mathrm{S} / \mathrm{L}$ genotypes have been associated with late-onset alcoholism, few pathological problems, few drinking-related problems, and childhood risk factors. The L/L genotype, on the other hand, has been associated with early-onset alcoholism, more severe psychopathology, antisocial and impulsive tendencies, childhood risk factors, and significant problems with alcohol. The neurobiological differences between these two subtypes may have significant implications for alcohol dependence pharmacotherapy. ${ }^{73,74}$

Results of clinical trials using SSRIs for the treatment of alcohol dependence in a heterogeneous group of alcoholics have produced mixed results. For example, among patients with alcohol dependence treated with fluoxetine $60 \mathrm{mg} /$ day, type A alcoholics did not differ significantly from the placebo group in measures of alcohol consumption while type B alcoholics (who have typically an early onset of alcoholism) had worse drinking outcomes. ${ }^{75}$ This finding of increased alcohol consumption with SSRIs in early-onset alcoholism was confirmed. ${ }^{72}$ However, this study also demonstrated that in late-onset alcoholism, treatment with sertraline $200 \mathrm{mg}$ /day was associated with fewer drinking days and a greater likelihood of continuous abstinence $(P=0.01$ and $P=0.004$, respectively). In contrast with patients having early-onset alcoholism, in patients with late-onset alcoholism, who have predominantly the $\mathrm{S} / \mathrm{S}$ or $\mathrm{S} / \mathrm{L}$ genotypes, SSRIs are thought to facilitate serotonergic neurotransmission and inhibition of dopamine, thereby decreasing the positive reinforcement and reward from acute alcohol consumption. ${ }^{3,68,72}$ Thus, these results may suggest that, among patients with alcohol dependence, patients with late-onset alcoholism may exhibit a favorable response to treatment with SSRIs, while patients with early-onset alcoholism may increase alcohol consumption.

To pursue this line of research further, Kranzler et al ${ }^{77}$ examined the moderating effects of the triallelic 5-HTTLPR in a 12-week, parallel-group, placebo-controlled trial administering up to $200 \mathrm{mg}$ of sertraline $(\mathrm{n}=63)$ or placebo $(\mathrm{n}=71)$ daily to 134 patients with alcohol dependence and compared the effects in late-onset alcoholics versus early-onset alcoholics. Kranzler et al augmented their model to test whether the effect of treatment varied over time and by 5-HTTLPR genotype. The $\mathrm{L}_{\mathrm{G}}$ and $\mathrm{S}$ alleles were grouped together as $\mathrm{S}^{\prime}$ (the lower expression allele) and the $\mathrm{L}_{\mathrm{A}}$ allele was designated as $\mathrm{L}^{\prime}$ (the higher expression allele). Analyses for this study included main and interaction effects of medication group, age at onset of alcohol dependence $(\leq 25$ years 
versus $>25$ years), and 5-HTT genotype on drinking outcomes. For $\mathrm{L}^{\prime} / \mathrm{L}^{\prime}$ patients alone, the effects of medication group varied as a function of age of onset, because at the end of treatment, late-onset alcoholics with $\mathrm{L}^{\prime} / \mathrm{L}^{\prime}$ alleles reported fewer drinking and heavy drinking days when treated with sertraline. Early-onset alcoholics on the other hand treated with sertraline, were significantly more likely to drink on a given day than those treated with placebo. While there was no difference on heavy drinking days between sertralinetreated and placebo-treated L'/L' late-onset alcoholics, earlyonset alcoholics treated with sertraline were significantly more likely than placebo-treated early-onset alcoholics to drink heavily on a given day. Hence, this was the first study in patients with alcohol dependence in whom analyses were performed by triallele, and demonstrated that while a certain subtype of patients with alcohol dependence may benefit $\left(\mathrm{L}^{\prime} / \mathrm{L}^{\prime}\right)$, use of SSRIs in a heterogeneous population (ie, early-onset alcoholics with $\mathrm{L}^{\prime} / \mathrm{L}^{\prime}$ alleles) must be done with caution, if at all. ${ }^{75-77}$ If confirmed, this study represents a clinically relevant example of pharmacogenetics based on the 5-HTTLPR genotype, given the possibility of identifying the best responders to a medication, as well as those patients who should not receive that medication.

In contrast with late-onset alcoholism in which relatively normal serotonergic neurotransmission is maintained, the $\mathrm{L} / \mathrm{L}$ genotype associated with early-onset alcoholism is thought to result in reduced intersynaptic 5-HT, thereby inducing a compensatory upregulation of the $5-\mathrm{HT}_{3}$ receptor. ${ }^{3,68,72}$ In response to acute alcohol consumption, upregulation of the $5-\mathrm{HT}_{3}$ receptor is hypothesized to result in an increase in dopamine release in the nucleus accumbens, ${ }^{79}$ thereby increasing the positive reinforcement and reward from alcohol use in these individuals. Furthermore, a significant association between the L/L genotype and compulsive alcohol craving in patients with alcohol dependence has also been reported. ${ }^{80}$ Studies have suggested that the $5-\mathrm{HT}_{3}$ antagonist ondansetron at $4 \mu \mathrm{g} / \mathrm{kg}$ twice a day may be a particularly effective treatment option for alcohol dependence among patients with early-onset alcoholism. ${ }^{69}$ Johnson et al reported that treatment with ondansetron resulted in a significant increase in the number and percentage of days abstinent in patients with early-onset alcoholism but not late-onset alcoholism. ${ }^{81}$

These results with ondansetron in early-onset alcoholicL/L genotype patients are clouded by findings that among non-treatment-seeking alcohol-dependent subjects homozygous for the L allele, those receiving ondansetron reported significantly fewer drinks per drinking day than $\mathrm{S}$ carriers during the 7 days prior to an alcohol drinking session. ${ }^{72}$
Further, this laboratory study was confirmed in 283 patients with alcohol dependence who were randomized by 5 -HTTLPR genotype, not age of onset, with additional genotyping for another functional single nucleotide polymorphism in the $3^{\prime}$-untranslated region, rs1042173, in a double-blind, placebo-controlled trial. ${ }^{82}$ Subjects received ondansetron or placebo for 11 weeks plus standardized cognitive behavioral therapy. The study reported that $\mathrm{L} / \mathrm{L}$ patients who received ondansetron $4 \mu \mathrm{g} / \mathrm{kg}$ twice a day had significantly fewer mean drinks per drinking day and a higher percentage of days abstinent compared with the placebo group. ${ }^{79}$ In ondansetron recipients, drinks per drinking day was significantly lower and percentage of days abstinent significantly higher in $\mathrm{L} / \mathrm{L}$ versus $\mathrm{S}$ carriers. ${ }^{82}$ Ondansetron L-homozygous subjects also reported significantly fewer drinks per drinking day and greater percentage of days abstinent than all other genotype and treatment groups combined. ${ }^{82}$ For both drinks per drinking day and percentage of days abstinent, 5-HTTLPR and rs 1042173 variants interacted significantly. ${ }^{82}$ Patients receiving ondansetron who had LL/TT alleles reported significantly fewer drinks per drinking day and a greater percentage of days abstinent than all other genotype and treatment groups combined. ${ }^{82}$ Thus, given the significant differences in treatment efficacy between sertraline and ondansetron and between subgroups, determination of alcoholism typology and genotype is becoming more valuable to understanding the potential for more effective treatment matching for alcohol dependence.

\section{Nicotine dependence}

Twin studies have suggested a genetic influence in the development of smoking behaviors such as nicotine dependence and especially smoking initiation. ${ }^{83}$ Moreover, the heritability of nicotine dependence and of smoking initiation is estimated to be $62 \%$ and $47 \%-76 \%$, respectively. ${ }^{84,85}$ The serotonergic system has been suggested to play a role in smoking behavior, because acute nicotine administration has been shown to increase release of 5-HT in the brain, and chronic nicotine use depletes 5 -HT stores. ${ }^{85}$ Further, since antidepressants have demonstrated efficacy in smoking cessation, ${ }^{86}$ it was theorized that 5-HTTLPR may influence smoking behavior. ${ }^{85,87}$

Kremer et al, investigating the influence of 5-HTT genotype on smoking behavior, reported a significantly greater frequency of the L-allele with the 12-repeat VNTR, a polymorphism also known to increase transcriptional activity of the gene, in both current and past smokers compared with nonsmoker controls. ${ }^{87}$ In addition, this association was 
significantly strengthened using combined current and past smokers compared with nonsmokers, yielding an estimated risk for these polymorphisms of 1.37 (95\% CI: 1.17-1.61). ${ }^{87}$ The authors theorized that low serotonergic tone associated with increased activity of the L allele may result in an increased sensitivity to 5-HT release, and resulting dopamine release in the nucleus accumbens, from acute nicotine use. ${ }^{87}$ Also, after smoking initiation, L carriers are thought to be at an increased risk of developing dependence due to the further reduction in 5-HT levels with chronic nicotine use. ${ }^{87}$

In an open-label randomized clinical trial of transdermal patch versus nasal spray nicotine replacement therapy for smoking cessation in 397 smokers. ${ }^{88}$ To assess smoking status, telephone interviews were conducted at the end of treatment and at 6-month follow-up. Munafo et al predicted that possession of one or more copies of the $\mathrm{S}$ allele of the 5-HTTLPR polymorphism would be associated with a reduced likelihood of successful smoking cessation. They also explored the possibility that nicotine replacement therapy delivered via nasal spray may be more effective than nicotine replacement therapy delivered via transdermal patch in smokers with one or more copies of the $S$ allele. The main effect of the 5-HTTLPR genotype was not associated with abstinence at either the end of treatment or at 6-month follow-up, and there was no evidence for a genotype $\times$ treatment interaction effect. All other effects were also nonsignificant, although the effect of nicotine dependence score on abstinence at 6-month follow-up approached statistical significance $(P=0.07)$. These results provide no support for an association between 5-HTTLPR genotype and smoking cessation in response to nicotine replacement therapy. ${ }^{88}$

\section{Attention deficit hyperactivity disorder}

Twin and adoption studies demonstrate a significant genetic influence in the development of attention deficit hyperactivity disorder (ADHD) and the heritability is estimated to be $76 \% .{ }^{89}$ While the serotonergic system is not targeted directly by stimulant drugs efficacious in the treatment of ADHD, it is thought that pharmacological alteration of the dopamine system by these drugs might influence 5 -HT transmission projecting downstream..$^{90}$ Moreover, some have hypothesized that SSRIs might be useful in the treatment of ADHD patients who do not respond to traditional pharmacotherapy or those with comorbid psychiatric disorders. ${ }^{91}$ Hence, it is theorized that the serotonergic system may play a role in mediating the effects of ADHD drugs and it has been suggested that 5-HTT genotype may affect predisposition to this disorder. ${ }^{90-92}$
In a study that assessed the association between 5-HTT genotype and hyperkinetic disorder with and without conduct disorder, the frequency of the L-homozygous genotype was significantly increased in patients with hyperkinetic disorder both with and without conduct disorder $(P=0.004) .{ }^{91}$ In addition, patients with the $\mathrm{L} / \mathrm{L}$ genotype scored significantly higher than patients with the $\mathrm{S} / \mathrm{L}$ and $\mathrm{L} / \mathrm{L}$ genotypes on the Wender Utah Rating Scale (WURS, an instrument used to measure ADHD-related symptoms) for the diagnosis of ADHD. ${ }^{93}$ Moreover, among participants who scored above 100 on the WURS, the frequency of the L allele was significantly increased..$^{93}$ In addition, another study demonstrated that the frequency of the S-homozygous genotype was significantly lower in patients with ADHD than in controls. ${ }^{94}$ Furthermore, a pooled OR for the L allele of 1.31 (95\% CI: 1.09-1.59) was reported for combined studies of the association between 5-HTTLPR and ADHD. ${ }^{92}$

Assuming that the serotonergic system is involved in the response to stimulant drugs used to treat $\mathrm{ADHD}$, the influence of 5-HTT genotype on response to methylphenidate $0.5 \mathrm{mg}$ / $\mathrm{kg} /$ day in children meeting DSM-IV diagnostic criteria for ADHD was examined by Thaker et al. ${ }^{90}$ While $\mathrm{L}_{\mathrm{A}}$ carriers responded significantly better to methylphenidate than placebo, patients without $\mathrm{L}_{\mathrm{A}}$ allele did not exhibit a significantly better medication response compared with placebo. ${ }^{90}$ In addition, patients without a $\mathrm{L}_{\mathrm{A}}$ allele demonstrated a significant improvement in symptoms in response to placebo compared with patients with one $\mathrm{L}_{\mathrm{A}}$ allele. ${ }^{90}$ Thus, patients with the lower expressing $\mathrm{L}_{\mathrm{G}}$ alleles and $\mathrm{S}$ alleles exhibited a significant improvement in symptoms in response to placebo and did not obtain additional benefit from methylphenidate, while $\mathrm{L}_{\mathrm{A}}$ carriers had minimal response to placebo and improved significantly with methylphenidate..$^{90}$

\section{Conclusion}

Classification of the genes responsible for heritable components of various psychiatric disorders is crucial to the advancement of our understanding of the underlying neurobiology and pathology of complex psychiatric diseases. Studies of the 5-HTTLPR polymorphism in psychiatry demonstrate a significant association with several disorders, with the $\mathrm{S}$ allele being the "risk allele" for numerous psychiatric disorders, putatively due to decreased transcriptional activity. The $\mathrm{S}$ allele may be associated with heightened amygdala response, anxiety-related personality traits, major depressive disorder, attempted suicide, and bipolar disorder. In contrast, the increased transcriptional activity of the $\mathrm{L}$ allele has been associated with completed suicide, nicotine dependence, 
and ADHD. Meanwhile, for some disorders, such as posttraumatic stress disorder, the association has not yet been fully characterized, and for other disorders, such as alcohol dependence, the association appears to vary with alcohol subtype. Also, in conditions such as major depressive disorder, alcohol dependence, ADHD, and possibly bipolar disorder, the 5-HTTLPR polymorphism has generally but inconclusively been shown to have important pharmacotherapy implications, particularly in certain subgroups.

The great difficulty in transferring these results to useful pharmacotherapeutic approaches is due to the often inconsistent and conflicting associations between 5-HTTLPR alleles and outcomes. Most but not all data appear to show that Caucasian individuals with major depressive disorder, particularly those with L alleles, appear to respond faster to treatment with SSRIs, but not tricyclic antidepressants, and that individuals with post-traumatic stress disorder and L alleles also respond to treatment with an SSRI.

An almost universal problem with studies on the association of the 5-HTTLPR is a lack of statistical power to detect what may be a relatively small effect, though it appears that methodologically sound statistical techniques can help to overcome this problem. Moreover, it appears probable that diseases as complex as psychiatric disorders have a complex genetic etiology, and are influenced by multiple genes and by interactions of genes within the environment. To this end, it seems that studies assessing the 5-HTTLPR as the only genetic factor contributing to the etiology of psychiatric disorders will continue to be affected by statistically small effect sizes and limited replication. Because a polygenic model for the etiology of these disorders seems to be the case, future studies should attempt to assess the confluence of candidate genes together rather than individually. This will allow for determination of the relative effect sizes of genes, as well as prevent confounding from the heterogeneous distribution of other non-controlled candidate genes between arms of single gene association studies. In addition, many of the studies reviewed assessed the association of 5-HTTLPR as a biallelic polymorphism and failed to account for the differential activity of the two distinct L-alleles. Because the $\mathrm{L}_{\mathrm{G}}$ allele has transcriptional activity similar to the $\mathrm{S}$ allele, and only the $\mathrm{L}_{\mathrm{A}}$ allele has been demonstrated to increase transcriptional activity, the $\mathrm{L} / \mathrm{L}$ genotype reported in some studies may in actuality be $\mathrm{L}_{\mathrm{G}} / \mathrm{L}_{\mathrm{G}}$, and thus would have activity comparable with the $\mathrm{S} / \mathrm{S}$ genotype, thereby confounding interpretation of the results. Thus, studies that treat the 5-HTTLPR as biallelic may underestimate its effect at best or report a result opposite to what may be the true association. Discovery of the triallelic 5-HTTLPR alleles may help explain the conflicting results of many past association studies, while at the same time providing more meaningful data in the future. We therefore strongly encourage researchers in future studies to report results based on the $5^{\prime}$ HTTLPR triallele consistently and to report effect sizes as well.

Once results have been validated in large, well-powered meta-analytic studies that consider the triallelic 5-HTTLPR as part of a psychiatric haplotype, these findings may have important potential. For example, if a large effect size can be determined for a single gene or a combination of genes, this genetic panel may be used to screen individuals and allow for determination of susceptibility to various psychiatric disorders. Additionally, if particular $\mathrm{G} \times \mathrm{E}$ interactions exist, genetic screening may allow for targeted prophylactic treatment after a stressful event in those at high risk. Moreover, genetically targeted treatment modalities in psychiatry may become a reality, allowing for the matching of the best drug for each unique individual.

In summary, there is considerable evidence that the 5-HTTLPR polymorphism has significant implications in the etiology of many psychopathologies, and in some cases, even pharmacotherapy outcomes. However, the full influence of the 5-HTTLPR polymorphism has not been completely elucidated nor confirmed. With the diffuse and varying functions of 5-HT, diseases and pharmacotherapies beyond those presented here may also be influenced by variation in the 5-HTTLPR.

\section{Acknowledgment}

This work has partially been supported by the National Institute on Alcohol Abuse and Alcoholism grant AA016079.

\section{Disclosure}

None of the authors declare any conflicts of interest in this work.

\section{References}

1. Mohammad-Zadeh LF, Moses L, Gwalzney-Brant SM. Serotonin: a review. J Vet Pharmacol Ther. 2008;31:187-199.

2. Sanders-Bush E, Mayer SE. 5-Hydroxytryptamine (serotonin): receptor agonists and antagonists. In: Brunton LL, Lazo JS, Parker KL, editors. Goodman and Gilman's: The Pharmacological Basis of Therapeutics. New York: McGraw-Hill; 2006.

3. Kenna GA. Medications acting on the serotonergic system for the treatment of alcohol dependent patients. Curr Pharm Des. 2010;16:2126-2135.

4. Lesch KP, Bengel D, Heils A, et al. Association of anxiety-related traits with a polymorphism in the serotonin transporter gene regulatory region. Science. 1996;274:1527-1531.

5. Caspi A, Hariri AR, Holmes A, Uher R, Moffitt TE. Genetic sensitivity to the environment: the case of the serotonin transporter gene and its implications for studying complex diseases and traits. Am J Psychiatry. 2010;167:509-527. 
6. Hariri AR, Mattay VS, Tessitore A, et al. Serotonin transporter genetic variation and the response of the human amygdala. Science. 2002;297:400-403.

7. Caspi A, Sugden K, Moffitt TE, et al. Influence of life stress on depression: moderation by a polymorphism in the 5-HTT gene. Science. 2003;301:386-389.

8. Matsushita S, Yoshino A, Murayama M, Kimura M, Muramatsu T, Higuchi S. Association study of serotonin transporter gene regulatory region polymorphism and alcoholism. Am J Med Genet. 2001;105: 446-450.

9. Hu X, Oroszi G, Chun J, Smith TL, Goldman D, Schuckit MA. An expanded evaluation of the relationship of four alleles to the level of response to alcohol and the alcoholism risk. Alcohol Clin Exp Res. 2005;29:8-16.

10. Lipsky RH, Hu XZ, Goldman D. Additional functional variation at the SLC6 A4 gene. Am J Med Genet B Neuropsychiatr Genet. 2009; $150: 153$.

11. Kuzelova H, Ptacek R, Macek M. The serotonin transporter gene (5-HTT) variant and psychiatric disorders: review of current literature. Neuro Endocrinol Lett. 2010;31:4-10.

12. Risch N, Herrell R, Lehner T, et al. Interaction between the serotonin transporter gene (5-HTTLPR), stressful life events, and risk of depression: a meta-analysis. JAMA. 2009;301:2462-2471.

13. Heils A, Teufel A, Petri S, et al. Allelic variation of human serotonin transporter gene expression. J Neurochem. 1996;66:2621-2624.

14. Heils A, Teufel A, Petri S, et al. Functional promoter and polyadenylation site mapping of the human serotonin (5-HT) transporter gene. J Neural Transm Gen Sect. 1995;102:247-254.

15. Gonzalez-Angulo AM, Hennessy BT, Mills GB. Future of personalized medicine in oncology: a systems biology approach. JClin Oncol. 2010;28: 2777-2783.

16. Roerig JL. Diagnosis and management of generalized anxiety disorder. J Am Pharm Assoc. 1999;39:811-821.

17. Heinz A, Braus DF, Smolka MN, et al. Amygdala-prefrontal coupling depends on a genetic variation of the serotonin transporter. Nat Neurosci. 2005;8:20-21.

18. Surguladze SA, Elkin A, Ecker C, et al. Genetic variation in the serotonin transporter modulates neural system-wide response to fearful faces. Genes Brain Behav. 2008;7:543-551.

19. Munafò MR, Brown SM, Hariri AR. Serotonin transporter (5-HTTLPR) genotype and amygdala activation: a meta-analysis. Biol Psychiatry. 2008;63:852-857.

20. Munafò MR, Freimer NB, Ng W, et al. 5-HTTLPR genotype and anxiety-related personality traits: a meta-analysis and new data Am J Med Genet B Neuropsychiatr Genet. 2009;150:271-281.

21. Willis-Owen SA, Turri MG, Munafò MR, et al. The serotonin transporter length polymorphism, neuroticism, and depression: a comprehensive assessment of association. Biol Psychiatry. 2005;58:451-456.

22. American Psychiatric Association. Diagnostic and Statistical Manual of Mental Disorders DSM-IV-TR Fourth Text Revision. Washington, DC: American Psychiatric Association; 2000.

23. Kendler KS, Gatz M, Gardner CO, Pedersen NL. A Swedish national twin study of lifetime major depression. Am J Psychiatry. 2006;163:109-114.

24. Vergne DE, Nemeroff CB. The interaction of serotonin transporter gene polymorphisms and early adverse life events on vulnerability for major depression. Curr Psychiatry Rep. 2006;8:452- 457.

25. Munafò MR, Durrant $\mathrm{C}$, Lewis G, Flint J. Gene $\mathrm{x}$ environment interactions at the serotonin transporter locus. Biol Psychiatry. 2009;65:211-219.

26. Karg K, Burmeister M, Shedden K, Sen S. The serotonin transporter promoter variant (5-HTTLPR), stress, and depression meta-analysis revisited: evidence of genetic moderation. Arch Gen Psychiatry. 2011;68:444-454

27. Coplan JD, Abdallah CG, Kaufman J, et al. Early-life stress, corticotropin-releasing factor, and serotonin transporter gene: A pilot study. Psychoneuroendocrinology. 2011;36:289-293.
28. Ressler KJ, Bradley B, Mercer KB, et al. Polymorphisms in CRHR1 and the serotonin transporter loci: gene $\times$ gene $\times$ environment interactions on depressive symptoms. Am JMed Genet B Neuropsychiatr Genet. 2010;153: 812-824.

29. Yu YW, Tsai SJ, Chen TJ, Lin CH, Hong CJ. Association study of the serotonin transporter promoter polymorphism and symptomatology and antidepressant response in major depressive disorders. Mol Psychiatry. 2002; 7:1115-1119.

30. Smeraldi E, Zanardi R, Benedetti F, Di Bella D, Perez J, Catalano M. Polymorphism within the promoter of the serotonin transporter gene and antidepressant efficacy of fluvoxamine. $\mathrm{Mol}$ Psychiatry. 1998;3:508-511.

31. Yoshida K, Ito K, Sato K, et al. Influence of the serotonin transporter gene-linked polymorphic region on the antidepressant response to fluvoxamine in Japanese depressed patients. Prog Neuropsychopharmacol Biol Psychiatry. 2002;26:383-386.

32. Kim DK, Lim SW, Lee S, et al. Serotonin transporter gene polymorphism and antidepressant response. Neuroreport. 2000;11:215-219.

33. Zanardi R, Benedetti F, Di Bella D, Catalano M, Smeraldi E. Efficacy of paroxetine in depression is influenced by a functional polymorphism within the promoter of the serotonin transporter gene. J Clin Psychopharmacol. 2000;20:105-107.

34. Pollock BG, Ferrell RE, Mulsant BH, et al. Allelic variation in the serotonin transporter promoter affects onset of paroxetine treatment response in late-life depression. Neuropsychopharmacology. 2000;23:587-590.

35. Durham LK, Webb SM, Milos PM, Clary CM, Seymour AB. The serotonin transporter polymorphism, 5HTTLPR, is associated with a faster response time to sertraline in an elderly population with major depressive disorder. Psychopharmacology. 2004;174: 525-529.

36. Lewis G, Mulligan J, Wiles N et al. Polymorphism of the 5-HT transporter and response to antidepressants: randomised controlled trial. Br J Psychiatry. 2011;198:464-471.

37. Huezo-Diaz P, Uher R, Smith R, et al. Moderation of antidepressant response by the serotonin transporter gene. Br J Psychiatry. 2009;195:30-38.

38. Keers R, Uher R, Huezo-Diaz R, et al. Interaction between serotonin transporter gene variants and life events predicts response to antidepressants in the GENDEP project. Pharmacogenomics. 2011;11:138-145.

39. Serretti A, Kato M, De Ronchi D, Kinoshita T. Meta-analysis of serotonin transporter gene promoter polymorphism (5-HTTLPR) association with selective serotonin reuptake inhibitor efficacy in depressed patients. Mol Psychiatry. 2007;12:247-257.

40. Taylor MJ, Sen S, Bhagwagar Z. Antidepressant response and the serotonin transporter gene-linked polymorphic region. Biol Psychiatry. 2010;68:536-543.

41. White KJ, Walline CC, Barker EL. Serotonin transporters: implications for antidepressant drug development. AAPS J. 2005;7:421-433.

42. Malone KM, Haas GL, Sweeney JA, Mann JJ. Major depression and the risk of attempted suicide. J Affect Disord. 1995;34:173-185.

43. Du L, Faludi G, Palkovits M, et al. Frequency of long allele in serotonin transporter gene is increased in depressed suicide victims. Biol Psychiatry. 1999;46:196-201.

44. Du L, Faludi G, Palkovits M, Bakish D, Hrdina PD. Serotonergic genes and suicidality. Crisis. 2001;22:54-60.

45. Russ MJ, Lachman HM, Kashdan T, Saito T, Bajmakovic-Kacila S. Analysis of catechol-O-methyltransferase and 5-hydroxytryptamine transporter polymorphisms in patients at risk for suicide. Psychiatry Res. 2000;93:73-78.

46. Anguelova M, Benkelfat C, Turecki G. A systematic review of association studies investigating genes coding for serotonin receptors and the serotonin transporter: II. Suicidal behavior. Mol Psychiatry. 2003;8:646-653.

47. Craddock N, Jones I. Genetics of bipolar disorder. J Med Genet. 1999;36:585-594. 
48. Cho HJ, Meira-Lima I, Cordeiro Q, et al. Population-based and family-based studies on the serotonin transporter gene polymorphisms and bipolar disorder: a systematic review and meta-analysis. Mol Psychiatry. 2005;10:771-781.

49. Anguelova M, Benkelfat C, Turecki G. A systematic review of association studies investigating genes coding for serotonin receptors and the serotonin transporter: I. Affective disorders. Mol Psychiatry. 2003;8:574-591.

50. Rotondo A, Mazzanti C, Dell'Osso L, et al. Catechol o-methyltransferase, serotonin transporter, and tryptophan hydroxylase gene polymorphisms in bipolar disorder patients with and without comorbid panic disorder. Am J Psychiatry. 2002;159:23-29.

51. Goldberg JF, Truman CJ. Antidepressant-induced mania: an overview of current controversies. Bipolar Disord. 2003;5:407-420.

52. Mundo E, Walker M, Cate T, Macciardi F, Kennedy JL. The role of serotonin transporter protein gene in antidepressant-induced mania in bipolar disorder: preliminary findings. Arch Gen Psychiatry. 2001;58:539-544.

53. Rousseva A, Henry C, van den Bulke D, et al. Antidepressant-induced mania, rapid cycling and the serotonin transporter gene polymorphism. Pharmacogenomics J. 2003;3:101-104.

54. Serretti A, Artioli P, Zanardi R, et al. Genetic features of antidepressant induced mania and hypo-mania in bipolar disorder. Psychopharmacology. 2004;174:504-511.

55. Lee HJ, Lee MS, Kang RH, et al. Influence of the serotonin transporter promoter gene polymorphism on susceptibility to posttraumatic stress disorder. Depress Anxiety. 2005;21:135-139.

56. Wang Z, Baker DG, Harrer J, Hamner M, Price M, Amstadter A. The relationship between combat-related posttraumatic stress disorder and the 5-HTTLPR/rs25531 polymorphism. Depress Anxiety. 2011;28:1067-1073.

57. Xie P, Kranzler HR, Poling J, et al. Interactive effect of stressful life events and the serotonin transporter 5-HTTLPR genotype on posttraumatic stress disorder diagnosis in 2 independent populations. Arch Gen Psychiatry. 2009;66:1201-1209.

58. Aas M, Djurovic S, Athanasiu L, et al. Serotonin transporter gene polymorphism, childhood trauma, and cognition in patients with psychotic disorders. Schizophr Bull. September 9, 2011. [Epub ahead of print.]

59. Mushtaq D, Ali A, Margoob MA, Murtaza I, Andrade C. Association between serotonin transporter gene promoter-region polymorphism and 4- and 12-week treatment response to sertraline in posttraumatic stress disorder. J Affect Disord. 2011. [Epub ahead of print.]

60. Grabe HJ, Spitzer C, Schwahn C, et al. Serotonin transporter gene (SLC6A4) promoter polymorphisms and the susceptibility to posttraumatic stress disorder in the general population. Am J Psychiatry. 2009;166:926-933.

61. Kilpatrick DG, Koenen KC, Ruggiero KJ, et al. The serotonin transporter genotype and social support and moderation of posttraumatic stress disorder and depression in hurricane-exposed adults. $\mathrm{Am}$ J Psychiatry. 2007;164:1693-1699.

62. Enoch MA, Goldman D. Genetics of alcoholism and substance abuse. Psychiatr Clin North Am. 1999;2:289-299.

63. Prescott CA, Kendler KS. Genetic and environmental contributions to alcohol abuse and dependence in a population-based sample of male twins. Am J Psychiatry. 1999;156:34-40.

64. Kweon YS, Lee HK, Lee CT, Lee KU, Pae CU. Association of the serotonin transporter gene polymorphism with Korean male alcoholics. J Psychiatr Res. 2005;39:371-376.

65. Johnson BA, Javors MA, Roache JD, et al. Can serotonin transporter genotype predict serotonergic function, chronicity, and severity of drinking? Prog Neuropsychopharmacol Biol Psychiatry. 2008;32:209-216.

66. McHugh RK, Hofmann SG, Asnaani A, Sawyer AT, Otto MW. The serotonin transporter gene and risk for alcohol dependence: a metaanalytic review. Drug Alcohol Depend. 2010;108:1-6.

67. Ait-Daoud N, Roache JD, Dawes MA, et al. Can serotonin transporter genotype predict craving in alcoholism? Alcohol Clin Exp Res. 2009;33:1329-1335.
68. Tartter MA, Ray LA. The serotonin transporter polymorphism (5-HTTLPR) and alcohol problems in heavy drinkers: moderation by depressive symptoms. Front Psychiatry. 2011;2:49.

69. Feinn R, Nellissery M, Kranzler HR, Meta-analysis of the association of a functional serotonin transporter promoter polymorphism with alcohol dependence. Am J Med Genet B Neuropsychiatr Genet. 2005;133:79-84.

70. Enoch MA, Gorodetsky E, Hodgkinson C, Roy A, Goldman D. Functional genetic variants that increase synaptic serotonin and 5-HT3 receptor sensitivity predict alcohol and drug dependence. Mol Psychiatry. 2011;16:1139-1146.

71. Herman AI, Kaiss KM, Ma R, et al. Serotonin transporter promoter polymorphism and monoamine oxidase type A VNTR allelic variants together influence alcohol binge drinking in young women. Am J Med Genet B Neuropsychiatr Genet. 2005;133:74-78.

72. Kenna GA, Zywiak WH, McGeary JE, et al. A within-group design of nontreatment seeking 5-HTTLPR genotyped alcohol-dependent subjects receiving ondansetron and sertraline. Alcohol Clin Exp Res. 2009;33:315-323.

73. Kenna GA, McGeary JE, Swift RM. Pharmacotherapy, pharmacogenomics, and the future of alcohol dependence treatment, Part 2. Am J Health Syst Pharm. 2004;61:2380-2388.

74. Kenna GA. Pharmacotherapy of alcohol dependence: Targeting a complex disorder. Drug Disc Today: Therapeutic Strategies. 2005;2:71-78.

75. Kranzler HR, Burleson JA, Korner P, et al. Placebo-controlled trial of fluoxetine as an adjunct to relapse prevention in alcoholics. Am J Psychiatry. 1995;152:391-397.

76. Pettinati HM, Volpicelli JR, Kranzler HR, Luck G, Rukstalis MR, Cnaan A. Sertraline treatment for alcohol dependence: interactive effects of medication and alcoholic subtype. Alcohol Clin Exp Res. 2000;24:1041-1049.

77. Kranzler HR, Armeli S, Tennen H, et al. Double-blind, randomized trial of sertraline for alcohol dependence: moderation by age of onset and 5-HTTLPR genotype. J Clin Psychopharmacol. 2011;31:22-30.

78. Johnson BA. Serotonergic agents and alcoholism treatment: rebirth of the subtype concept - an hypothesis. Alcohol Clin Exp Res. 2000;24:1597-1601.

79. Hammoumi S, Payen A, Favre JD, et al. Does the short variant of the serotonin transporter linked polymorphic region constitute a marker of alcohol dependence? Alcohol. 1999;17:107-112.

80. Bleich S, Bönsch D, Rauh J, et al. Association of the long allele of the 5-HTTLPR polymorphism with compulsive craving in alcohol dependence. Alcohol Alcohol. 2007;42:509-512.

81. Johnson BA, Roache JD, Javors MA, et al. Ondansetron for reduction of drinking among biologically predisposed alcoholic patients: A randomized controlled trial. JAMA. 2000;284:963-971.

82. Johnson BA, Ait-Daoud N, Seneviratne C, et al. Pharmacogenetic approach at the serotonin transporter gene as a method to reduce severe alcohol consumption. Am J Psychiatry. 2011;168:265-275.

83. Kendler KS, Neale MC, Sullivan P, Corey LA, Gardner CO, Prescott CA. A population-based twin study in women of smoking initiation and nicotine dependence. Psychol Med. 1999;29:299-308.

84. Heath AC, Madden PA, Slutske WS, Martin NG. Personality and the inheritance of smoking behavior: a genetic perspective. Behav Genet. $1995 ; 25: 103-117$

85. Arinami T, Ishiguro H, Onaivi ES. Polymorphisms in genes involved in neurotransmission in relation to smoking. Eur J Pharmacol. 2000;410:215-226.

86. Hughes JR, Stead LF, Lancaster T. Antidepressants for smoking cessation. Cochrane Database Syst Rev. 2007;(1):CD000031.

87. Kremer I, Bachner-Melman R, Reshef A, et al. Association of the serotonin transporter gene with smoking behavior. Am J Psychiatry. 2005;162:924-930.

88. Munafò MR, Johnstone EC, Wileyto EP, Shields PG, Elliot KM, Lerman C. Lack of association of 5-HTTLPR genotype with smoking cessation in a nicotine replacement therapy randomized trial. Cancer Epidemiol Biomarkers Prev. 2006;15:398-400. 
89. Biederman J, Faraone SV. Attention-deficit hyperactivity disorder. Lancet. 2005;366:237-248.

90. Thakur GA, Grizenko N, Sengupta SM, Schmitz N, Joober R. The 5-HTTLPR polymorphism of the serotonin transporter gene and short term behavioral response to methylphenidate in children with ADHD. BMC Psychiatry. 2010;10:50.

91. Seeger G, Schloss P, Schmidt MH. Functional polymorphism within the promotor of the serotonin transporter gene is associated with severe hyperkinetic disorders. Mol Psychiatry. 2001;6:235-238.

92. Faraone SV, Perlis RH, Doyle AE, et al. Molecular genetics of attentiondeficit/hyperactivity disorder. Biol Psychiatry. 2005;57:1313-1323.
93. Retz W, Thome J, Blocher D, Baader M, Rösler M. Association of attention deficit hyperactivity disorder-related psychopathology and personality traits with the serotonin transporter promoter region polymorphism. Neurosci Lett. 2002;319:133-136.

94. Zoroğlu SS, Erdal ME, Alaşehirli B, et al. Significance of serotonin transporter gene 5-HTTLPR and variable number of tandem repeat polymorphism in attention deficit hyperactivity disorder. Neuropsychobiol. 2002;45:176-181.

\section{Publish your work in this journal}

Pharmacogenomics and Personalized Medicine is an international, peerreviewed, open access journal characterizing the influence of genotype on pharmacology leading to the development of personalized treatment programs and individualized drug selection for improved safety, efficacy and sustainability. This journal is indexed on the American Chemical
Society's Chemical Abstracts Service (CAS). The manuscript management system is completely online and includes a very quick and fair peer-review system, which is all easy to use. Visit http://www.dovepress. $\mathrm{com} /$ testimonials.php to read real quotes from published authors.

Submit your manuscript here: http://www.dovepress.com/pharmacogenomics-and-personalized-medicine-journal 